\title{
Trellis and Vine: Discipleship
}

\section{Book Title:}

The Trellis and the Vine.

The ministry mind-shift that

changes everything

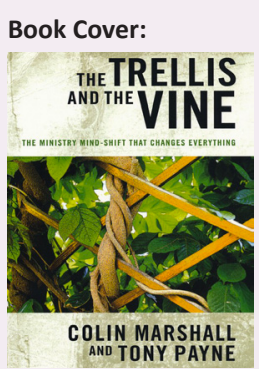

Authors:

Colin Marshal

Tony Payne

ISBN:

978-1-921441-58-5

Publisher:

Kingsford: Matthias Media,

2009, R149.80*

*Book price at time of review

-

Review Title:

Trellis and Vine: Discipleship

Reviewer:

Raymond Potgieter ${ }^{1}$

Affiliation:

${ }^{1}$ Faculty of Theology, North-

West University, South Africa

Email:

ray@csmdist.com

Postal address:

PO Box 19491, Noordbrug

2522, South Africa

How to cite this book review:

Potgieter, R., 2013, 'Trellis

and Vine: Discipleship',

In die Skriflig/In Luce Verbi

47(1), Art. \#1709, 2 pages.

http://dx.doi.org/10.4102/

ids.v47i1.1709

\section{Copyright:}

(C) 2013. The Authors.

Licensee: AOSIS

OpenJournals. This work

is licensed under the

Creative Commons

Attribution License.

Read online:

Scan this QR
code with your
smart phone or
mobile device
to read online.

Some time ago, a colleague in church ministry gave me a copy of The Trellis and the Vine. There was an underlying excitement in his recommendation of the book. It has taken some time, but I finally read it and I want to share some insights from the book with you.

Using the metaphor of the vine, as well as the supplementary trellis metaphor in the sense of it supporting the function of the vine, Marshall and Payne provide a useful analysis of particularly the local congregation. These metaphors are drawn from, for instance, Psalm 80 and Hosea 14:4-7, until finally centring in the 'I am the true Vine' of John 15:1-11 (pp. 29-37) to conclude that the biblical emphasis of growth is 'the growth of the gospel, as it is spoken and respoken under the power of the Spirit' (p. 37).

With that established, the authors spend some time on the function of the church, understanding the vine to represent people involved in disciple-making. The trellis is seen as referring to church structures and associated programs. Bearing this distinction in mind, there is little reason to confuse the trellis (church structure and administration) as becoming the reason for ministry in the church. That error, according to its authors, is the reason for weak church ministry, with persons absent from church services, neglecting prayer and being careless in their Christian testimony, while ministers work hard with little to show, and so on (p. 8f.). Vital energy is spent on maintaining the trellis' programs and ensuring that its plans are well funded and supported, and meet the needs of the congregation. Not that these things in themselves are bad, but can you imagine spending the same energy on the vine, translating that into organic dynamism!

What a relief for ministers. Here is a book about their congregations and the church as a whole (2 Tm 2:2), and how to get involved in the original purpose of the church: the making of disciples seen as the ongoing work of Jesus in building his church (p. 37) - a discipleship ministry that impacts the whole of life and living extending from the home to the factory and office (p. 166). Not to exclude other tasks in the church, but this is 'vine work' (p. 39).

The authors make much of the one-on-one discipleship method, but realise that preconceived mindsets have to be dealt with. Often a minister is seen as the one paid to do ministry, growing the church, initiating programs, and so on, and then consequently the one to blame if the church is not experiencing 'growth'. Marshall and Payne spend time on how to effect a mindshift towards a biblical view of ministry among people (p. 26). As this occurs, there develops a mature discernment by the minister and leaders on how to involve members of the congregation - not in programs, but in the movement (p. 57) of 'vine work'. Illustratively, here is the immediate solution for any minister faced with an enthusiastic offer from a person or family to get involved in the church (p. 27f.). Generally, the first thing that crosses the minister's mind is possibly something like: 'Now where on earth can I slot you in?'. That is thinking in terms of 'jobs' for people. Since most of the jobs are generally taken, not only is there little scope for a person with this job mindset in the congregation, it is also quite contrary to the Titus model, or that of 1 Corinthians 15:58 (p. 58). Rather, the prayerful speaking of the Word of God to another person is the key focus, with the minister and leadership taking active part in discipling others to do the same. The authors make much of the controversial Richard Baxter (p. 104f.), whose Reformed Pastor is one of the beloved Puritan classics dealing with the task of reaching a community with the Gospel. Ongoing ministry is part of the vine concept - a dynamic growing experience among those engaging in this ministry to enliven a church to become a fruit-bearing vine because the Holy Spirit is at work where the Gospel is preached (p. 73).

In essence, the authors envision two things:

- A period of deeper commitment to ministry excellence and maturity through some of the identified disciples invited to join a more extended discipleship program for two years, with some even being commissioned to go to seminary. This will ensure a tried and tested seminarian and family (chapters 6 and 11), as well as a process of nurtured persons nurturing others (chapter 12). 
- The focus is not programs and their continued maintenance, but rather on what the Lord provides his vine for the development of people, not church growth (p. 151). This means that if a congregational program has reached its sell-by date, then it is shelved instead of maintained. The congregation moves on. This allows the discipleship of people to bring about a richer Spirit-led ministry, breaking the stifling hold structures have on organic ministry. But it also challenges the Reformed congregation to spotlight their minister from within the new mindset - that he and/ or she is part of a team. In this view, the congregation is seen as a team comprising of individuals, and its leaders as a team within the team (p. 94ff.).

Now, this gossiping the Gospel with another may include church members, new Christians and those on the fringe of Christianity, or it might include those on the street where you live. The point is not to meet for frivolous conversation, but for reading the Word of God, discerning what God is saying to both of you - not only to the one who is being engaged.

But how does this begin? It could start with the minister training one other, who in turn trains another, and so multiplying the training until the church is one of engagement. Any minister questioning this ought to revisit the core assumptions about ministry. It is about people - not about programmes, administration and meetings.
This book is not unique and some of its principles are found in similar books on the subject, such as Total church: A radical reshaping around gospel and community by Tim Chester and Steve Timmis, and The church: The gospel made visible by Mark Dever. But I do recommend it for its focus on the vine metaphor and the natural development of that concept, weighed by the fact that biblical principles of this book have been tried and tested in churches around the world (p. 143). To see Christian living is to see Biblical Theology in action, translating into conscious and joyous living for Christ. This engagement of living and speaking scripture at home and in community will simply confirm a wider latitudinal understanding of the Reformed confessional understanding of what church is like in its marks of preaching the Word, administration of the sacraments and church discipline.

A bonus is the CD, which is provided in a plastic holder inside the back cover of the book. A series of short video clips has Tony Payne introducing the content of The Trellis and the Vine, as well as some of the worthwhile resources available from Matthias Media.

For these reasons, I think that this book might serve as the ideal book for the minister and the church leaders to read together, and discuss and implement its organic principles in their own unique situations. 